\author{
Iryna V. Kovalchuk \\ ORCID ID: 0000-0002-4740-4139 \\ Olena O. Popivniak \\ ORCID ID: 0000-0002-7998-7965
}

\title{
TEXTUALITY STANDARDS OF GOODS LABELS AND PACKAGING
}

\begin{abstract}
This article deals with the food and drink names. Special attention is given to the peculiarities of goods names in the context of textuality. Names of the beverages and eatables verbalize all features, qualities and individual characteristics of these goods. They create the naming space that consists of four nominative components: brand, individual, genitive, and functional descriptive. These nominative components create the text of labels and packages. Four nominative components function as corresponding text information blocks. It means that food and drink names labels combine two spaces. The first space is naming that is represented with the integrated naming complex. The complex grasps four nominative components. The second space is informational that stores the necessary volume of information and creates a communicative background. The information scope is kept in the text construction. The whole volume is divided into four relevant text blocks. Together all these blocks form text boundaries which outline the text construction. This text construction is characterized with two interdependent features coexisting in the integrated naming complex such as cohesion and coherence. Cohesion is realized on the lexical level involving the mechanism of repetition which is the part of the interaction. On the other hand, the repetition may be complete (the naming unit is repeated literally) and partial (the naming unit is repeated partly). The repetition may be between nearest blocks (having common boundary) and distant blocks (without common boundary). There is some peculiarity in the structure of functional-descriptive text block which functions as a set of subblocks. These subblocks are grasped into four subblock clusters. It indicates that description of goods properties and their usage instructions are significant in the text construction of labels and packages. The results of the research broaden the set of naming units adding to word, phrase, and sentence the next unit recognized as a text.
\end{abstract}

Key words: beverage, foodstuffs, label, packaging, text block, text subblock. 
Information about the authors: Kovalchuk Iryna Valeriyvna - PhD, Assistant Professor at the Department of English Philology and Intercultural Communication; Educational and Scientific Institute of Philology; Taras Shevchenko National University of Kyiv.

Popivniak Olena Oleksiyvna - PhD, Assistant Professor at the Department of English Philology and Intercultural Communication; Educational and Scientific Institute of Philology; Taras Shevchenko National University of Kyiv.

E-mail: irkov@hotmail.com; olenapopivniak@ukr.net

\author{
Ковальчук I.B. \\ ORCID ID: 0000-0002-4740-4139 \\ Попівняк 0.0 . \\ ORCID ID: 0000-0002-7998-7965

\section{СТАНДАРТИ ТЕКСТУАЛЬНОСТІ ТОВАРНИХ ЕТИКЕТОК І УПАКОВОК}

\begin{abstract}
Анотація. Ця стаття пов'язана з номінацією харчових продуктів та напоїв. Особлива увага звертається на виявлення у товарних назвах ознак текстуальності. Назви напоїв $i$ харчових продуктів вербалізують усі властивості, якісні та індивідуальні характеристики товарних об'єктів. Разом вони утворюють номінативний простір, що складається з чотирьох номінативних компонентів: брендового, індивідуального, родового $i$ функиіонально-дескриптивного. Усі ијі номінативні компоненти формують тексти етикеток $i$ упаковок. Чотири номінативні компоненти функціонують як відповідні текстові інформачійні блоки. Це означає, щчо назви на етикетках продуктів і напоїв об'єднують два простори. Першим простором $\epsilon$ номінативний, який окреслюється інтегрованим номінативний комплексом. Комплекс охоплюе чотири номінативні компоненти. Другим простором є інформачійний, що зберігає необхідний обсяг інформації і створює комунікативне підтрунтя. Інформаційний ядро зберігається у текстовому конструкті. Увесь обсяг розмежовується на чотири релевантні текстові блоки. Усі разом всі блоки формують текстові кордони, щзо окреслюють текстовий конструкт. Цей текстовий конструкт характеризується двома незалежними параметрами, що співіснують в інтегрованому номінативному комплексі - це когезія і когеренція. Когезія реалізується на лексичному рівні, використовуючи механізм повторення, що є окремим випадком реітераціï. 3 іншого боку, повторення може бути повним (номінативна одиниця повторюється дослівно) або частковим (номінативна одиниия повторюеться фрагментарно). Повторення може бути між суміжними блоками, що мають спільний кордон, а
\end{abstract}


також між віддаленими блоками, щзо не мають спільного кордону розмежування. Спостерігаються специфічні ознаки у структурі функиіонально-дескриптивного блоку. Пов'язано це з тим, щяо він функиіонує як сукупність підблоків. Самі иі підблоки об'єднані у чотири кластери. Це засвідчує той факт, щчо опис товарних характеристик конструкцій до їхнього споживання, використання $\epsilon$ доволі значущим у межах текстового корпусу етикеток $i$ упаковок товарів. Результати цього дослідження розширюють набір номінативних одиниць, додаючи до вже звичних слова, словосполучення $i$ речення ще одну номінативну одиницю, що визначається як текст.

Ключові слова: етикетка, напій, текстовий блок, текстовий підблок, упаковка, харчовий продукт.

Інформація про авторів: Ковальчук Ірина Валеріївна - кандидат філологічних наук; асистент кафедри англійської філології та міжкультурної комунікації; Навчально-науковий інститут філологї;; Київський національний університет імені Тараса Шевченка.

Попівняк Олена Олексіївна - кандидат філологічних наук; асистент кафедри англійської філології та міжкультурної комунікації; Навчально-науковий інститут філологї̈; Київський національний університет імені Тараса Шевченка.

Електронна aдреса: irkov@hotmail.com; olenapopivniak@ukr.net

\author{
Ковальчук И.В. \\ ORCID ID: 0000-0002-4740-4139 \\ Попивняк Е. $A$. \\ ORCID ID: 0000-0002-7998-7965

\section{СТАНДАРТЫ ТЕКСТУАЛЬНОСТИ ТОВАРНЫХ ЭТИКЕТОК И УПАКОВОК}

Аннотация. Результать данного исследования отображают специфику номинации пищевых продуктов и напитков. Пристальное внимание уделяется обнаружению у товарных названий признаков текстуальности. Названия напитков и пищевых продуктов вербализуют все свойства, качественные и индивидуальные характеристики товарных объектов. Вместе с тем эти названия образуют номинативное пространство, состоящее из четырех номинативных компонентов: брендового, индивидуального, родового и функционально-дескриптивного. Все вместе эти номинативные компоненты формируют тексты этикеток и упаковок. Четыре номинативных компонента функиионируют как соответствующие текстовые информачионные блоки. $B$ свою очередь, это свидетельствует, что названия на этикетках продуктов и напитков 
Випуск XLIII

объединяют два пространства. Первым является номинативное пространство, очерченное интегрированным номинативный комплексом. Сам комплекс охватывает все четыре номинативных компонента. Вторым пространством является информационное, сохраняющее необходимый объём информации и создающее коммуникативный фундамент. Информачионное ядро сохраняется в текстовом конструкте. Весь его объём разделяется на четыре релевантных текстовых блока. Все вместе эти текстовые блоки формируют текстовую гранииу, которая очерчивает текстовый конструкт. Сам по себе текстовый конструкт характеризуется двумя независимыми параметрами, которые сосуществуют в интегрированном коммуникативном комплексе: это когезия $и$ когеренция. Когезия реализуется на лексическом уровне, используя механизм повторения, являющегося частным случаем реитерачии. С другой сторонь, повторение может быть сплошным (номинативная единица повторяется дословно) или частичным (номинативная единица повторяется фрагментарно). Повторение может происходить между соседними блоками, а также между отдаленными блоками, не имеющими общей гранищь. Наблюдаются также специфические признаки в пределах функииональнодескриптивного блока. Связано это с тем, что данный блок функиионирует как совокупность подблоков. Сами эти подблоки объединены в четыре кластера. Это указывает на то, что описание товарных характеристик $u$ инструкций их употребления $u$ использования является достаточно значимым в пределах текстового конструкта этикеток и упаковок товаров. Результать данного исследования расширяют набор номинативных единии, добавляя $\kappa$ уже известным слову, фразе и предложению ещё одну номинативную единииу, определяемую как текст.

Ключевые слова: напиток, пищевой продукт, текстовый блок, текстовый подблок, упаковка, этикетка.

Информация про авторов: Ковальчук Ирина Валериевна кандидат филологических наук; ассистент кафедры английской филологии и межкультурной коммуникации; Учебно-научный институт филологии; Киевский национальный университет имени Тараса Шевченко.

Попивняк Елена Алексеевна - кандидат филологических наук; ассистент кафедры английской филологии и межкультурной коммуникации; Учебно-научный институт филологии; Киевский национальный университет имени Тараса Шевченко.

Электронный aдрес: irkov@hotmail.com; olenapopivniak@ukr.net

The cognitive activity of people improves the language development. The process of communication stimulates the 
formation of new texts, the biggest communicative units. The increase in the field of new object production is also reflected in linguistic units of different levels. Commerce activity is a branch of society's activity. It is associated with manufacturing and selling different goods. These activities are reflected in naming units. Foodstuffs and drink naming units reflect the results of those activities. The new naming units accompany new eatables and beverages providing essential amount of information for buyer's navigation in the huge field of food labelling and packaging. Modern English naming is polyaspect phenomenon grasping different linguistic units, levels according to their features and functions. Naming process reflection can be investigated on the bases of eatables and beverages in particular. Food and drink names create an individual subclass in the global goods naming sphere. Using these names consumers can get essential information. Products are realised in two huge groups: foodstuffs- eatables and drinks- beverages. The semantic aspect of food and drink naming is the most variable component reflecting the emotional, cognitive and social stratification intention of produces - nominators.

The purpose of the article is to conduct the research of the food and drink names taking into consideration the text nature these naming units. Food and drink goods belong to the objects which are consumed in vast amounts, they are necessary and essential for everyone being in constant demand. The main problem of these goods is their variability. Their variety is reflected in different labels and package design involving different naming units. Therefore the naming units have some text peculiarities which require attentive consideration. The topicality of the article lies in the fact that textual properties of food and drink names have not been analyzed in the way of correlating texts of labels and package. The scientific novelty of the research arises from the necessity of filling the gap that appears between naming units and texts which are involved in the process of naming and describing food and drink. Naming units are traditionally correlated with the words, phrases, and sentences. There is no attempt to find out the definite correlation between name and unit and text taking into 
consideration the fact that the text grasps all features of lower linguistic level units. The object of this research is a set of food labelling and packaging (500 labels of consumer goods and 1100 pictures of packages). The subject of the investigation is the text categories which may be identified within the naming complexes represented in labels and packages.

Literature review. According to Beaudrande and Dressler's ideas [1, p.37] text describes and explains the common and different features among the text types: what standards fulfill texts, how they are produced and perceived, who is using them in a given set of occurrences and so forth. The research of interaction in written form is traditionally recognized as a complete unit of speech (macrotext) and a set of linked utterances chained together with a common purpose of communication (microtext). It deals with the organisation of the text itself which is a language unit. The text is any written record of communicative event [2, p.26]. Being the highest and biggest communicative unit text corresponds to seven standards of textuality: cohesion, coherence, intentionality, informality, situationality and intertextuality [4, p.46]. All these standards features-traits outline the form of behaviour identified as textual communicating; and if defined, that form of behaviour will breakdown [3, p.118]. As cohesion and coherence are the first in the line of textuality standards, they should be researched as the leading, main text categories which may be found and revealed in this structure of texts - bearers representing food labelling and packaging and foodstuff names. These names are the products of food and drink naming processes. Thus, the final result of all these processes is the formation of the integrated naming complex (INC) [10] which is reflected in labels and packaging. Within the naming complex - text there is the combination of two spheres: informational and naming. The first sphere correlates to the direct name of things [11, p.72]. They belong to the main expressive units of language which ensure the thought-forming function of language [12, p.121].

Results. Text of packaging the foodstuffs, eatables, beverages have polyaspect and integrated nature. It means that these texts are grouped into a specific text type which bears the definite goods name 
and simultaneously it forms the label of the same goods. Goods names, which are represented in a verbal way on corresponding labels-packaging, being definitely naming units demonstrate some features of text as the biggest communicative linguistic unit. In the process of research, it is necessary to separate naming unit functions and the text linguistic tasks and specifications. The informational space of food and drink goods may be varied but in general, it looks like the following: Jordans Supreme Muesli. 50\% Fruit \& Nuts. An exquisite blend of cereal, dried fruit \& nuts. The naming space is divided into four nominative components. The same line of lexemes may be subdivided into A-component (Jordans), B-component (Supreme), C-component (Muesli), D-component (50\% Fruit \&Nuts. An exquisite blend of cereal, dried fruit \& nuts). If the INC is recognised as text, distinguished $\mathbf{A}, \mathbf{B}, \mathbf{C}$, and $\mathbf{D}$-components may be recognised as the text segmental blocks. Precise, efficient text block order in all INC helps to put forward the idea about logical relations between the text blocks. There is a definite and clear connection between the text block order and coherence. This text category is associated with a logical topical connection [18, p.410]. It shows how the components of the textual world, i.e. the configuration of concepts and relations which underlie the surface text, are mutually accessible and relevant [14, p.140-141]. The concept is definable as a configuration of knowledge (cognitive content) which can be recovered or activated with more or less unity and consistency in the mind: each link would bear a designation of the concept it connects to [6, p.291]. The results of label and packaging verbal component analysis have indicated the existence of twenty text elements, and according to US, Britain, Australia, New Zealand Food Standards [5, $7,8,9,16]$, ten of them are recognised as obligatory elements, others are optional. The list of obligatory elements grasps: name of manufacturer, name of product, address of manufacturer, date mark, list of ingredients, special storage condition, lot identification, net content, government warning, indication of alcoholic strength. Optional elements include: country of origin, nutrition information, health warning, instructions for use, advertisement claim, advertisement, nutrition claims, health claims, percentage labelling, 
GMO mark. The clear correlation between goods names, their components and text blocks was found in the case of perfume and cosmetic labels [10]. The same process is possible in the case of food labelling which enables to define common and specific tendencies for that class of goods.

Name of manufacturer begins the label text and is recognised as A-brand text block correlating with the introductory nominative component. A-brand text block containing only a name of manufacturer according to its structure may be subdivided into monocomponent and polycomponent nominative lexical units. Monocomponent brand names indicating corporations, manufacturers, trade shops and being nominative lexical units were created in different ways. Half of them were formed involving abbreviation (GSK, KAO), acronymization ( $A S D A$, Tesco), blending of roots or words (Hannaford, Walmart, Carrefour, Safeway). Using minimum lexicographic means text sender preserves the semantic level completeness in message. Trade shops create their own brand name components (A-brand text blocks). These naming units function as informative and identification structures and they are modifications for names of manufacturers: ASDA- Extra Special, Butcher's Selection, Smart Price; Tesco - Everyday Value, New Range, Free From, Finest, Organic. A-text block is a leading attractant in goods and productions of foodstuff firms. It helps the potential food, drink consumer to realize the primary navigation among the varieties of eatables and beverages presented by manufacturers. It is a conventional marker of price, quality and social segment of buyers-consumers. A-text block conventionality is connected with associations created in the society. Brand names manifest and proclaim corresponding quality, price, and connection with a certain social group of consumers. The set of associations creates the convention which goes far and is spread within all products of that brand name. A-text block as the initial structural component in the text construction starts the process of logical giving the relevant information about corresponding goods. The hidden target to A-text block is to attract the buyer's attention, to incline and 
persuade the potential consumer for buying goods of that brand name. A-text block starting the process of giving information about goods builds up the logical sequence of further text blocks initiating the formation of text coherence. Within the informational sphere of goods labels A-text block distinguishes goods of different manufacturers within one goods group: A Heinz Tomato Ketchup A Hellmann's Tomato Ketchup - A Tiptree Tomato Ketchup; A Cow \& Gate Creamed Porridge - A HiPP Organic Creamed Porridge Breakfast. A- brand text block demonstrates certain motivation relations in the process of manufacturer's naming. Possessive nominations dominate (32\%).

Owners' names are used in the process of transonymisation (owner's name $=$ onyme $1 \rightarrow$ brand name $=$ onyme2): A Robert Wiseman Dairies, A Rossi Ice Cream, A Burton's Food, A Fox's Biscuits, A Irwin's Bakery, A Millie's Cookies, A Ella's Kitchen. Associative nominations are on the second position (29\%). A-brand text blocks are created involving features of definite goods in every individual case: A Sassy, A Tommee Tippee (goods for babies and infants), A Organix (biscuits for children), A Savour Bakes (crackers), A The Pantry Essentials (flour), A Cow \& Gate (children's feeding), A Skinny Sweets (candies). Locative nominations are on the third position (17\%). These A-brand text blocks indicate the place of production and often imitate pronunciation and spelling of foreign origin: A Stoll work (Swiss chocolate), A Cucine (spaghetti), A Northern Catch (salmon fillet), A Whole Earth (organic muesli), A Morland Brewery (beer), A Belhan Brewery (beer), A Florida's natural (orange juice). Symbolic nominations are on the fourth position (9\%): A Green \& Black's (organic dark chocolate), Homepride (spices and sources). If A-brand text block (simultaneously A-brand name component) is identified definitely and clearly, there are some difficulties in identification of other text blocks within the food labels. Perfume and cosmetic goods packaging demonstrate definite label text division into separate blocks: A-brand text block (Dior), B-individual text block (Hypnotic poison), C-genitive text block (eau 
de perfume), D- functional descriptive text block (spray, 50ml, Paris). The problem is connected with the case the two text blocks may be identified separately or recognised is a closely connected structure, B-individual text block follows A-brand text block, supporting its informational function, broadening informational sphere, adding some further information, B-individual text block may be separated within INC as an individual goods name. B-individual text block occurs in the advertisements and catalogues. This block is associated with the goods names. From the functional point of view and logical connection, B- individual text block is closely related to A-brand text block. These A- and B-blocks cooperate and persuade the potential consumer to buy goods under the definite brand (A-block) and definite goods name (B-block). B-block varies, using different lexical and phrase units: (A)Hellmann's (B) bring out the best; (A) Jacob's (B) Cheddars; (A) Kraft Foods (B) Philadelphia; (A) Milupa (B) Sunshine Orange; (A) ASDA (B) Smart Price. Functioning together, A- and B -text blocks compensate for a lack of information and help the recipients to choose necessary foodstuffs. In any case, the compensation for information is not complete. From the logical point of view, the recipient needs the navigation in the sphere of goods classification.

Consequently, the next $\mathbf{C}$-text block works as a goods classifier and may be understood as a genitive text block. It contains information about eatables, beverages, indicating directly the class or type using the genitive name. It shows definitely that the corresponding goods belong to muesli, spaghetti, ketchup, vermicelli, ravioli, macaroni, béchamel, puree, cutlet, flambé, garnish, marinade, escalope, fillet, baguette, caramel, croissant, crepe, eclair, mousse, tart, broccoli, pizza, cappuccino, salami, curry, porridge, cookies, biscuits, ice cream, sweetie, flour, beer, juice. Cgenitive text block is a definite classifier which is restricted within the terminology system and works to inform a potential customer about the goods classes. represented in C-block information is purely connected with the physical and chemical properties of corresponding goods. From the logical point of view $\mathbf{C}$-text block is 
the final one in the chain of essential and necessary information about goods. The last D-text block which contains additional facultative information about the goods may be distinguished as functional-descriptive. This D-text block is divided into separate semi-independent subblocks. These sub blocks contain some pieces of information about the goods which need detailed description if we compare a rather brief description in A-, B- and C- text blocks. D-functional-descriptive text block grasps 18 subblocks in four subblock clusters. These clusters are built up according to the type of information which is described in corresponding subblocks. The first cluster contains manufacturer's information set grasps two subblocks. Address of manufacturer: (A) Nestlé, (B) Carnation, (D) We'd like to hear from you! please call1-800-637-8538, Mon-Fri,8 AM to 4:30 PM Pacific. (A) Del-Rio, (B-C) Orange Smoothie, (D) specially produced for ALDI stores, PO Box 26, Atherstore, Warwikshire, CV9 2SH, ALDI stores (Ireland) LTD, Po Box 726, Maas, Co Kildare. Visit us at www.aldi.com. (A) Kellogg's, (B-C) Pop-Tarts, (D) Kellogg company appreciate consumer comments. Call weekdays 8 am to 8pm: 1-800-962-1516. Write: P.O. BOXCAMB, Battle creek, MI, 49016-1986. (A) Lipton, (B-C) Cup-a-Soup, (D) Questions? Comments? please keep this package and call 1-800-697-7887, or write to the address on this package. Address of manufacturer subblock is given according to the labelling requirements and acts, representing all possible ways of contacting manufacturers. The second subblock within manufacturer's information cluster is country of origin, place of origin. This subblock contains phrases: produced in, made in, product of. This information is necessary for avoiding disinformation of a potential consumer: Turkish Delight made in the UK.

The biggest cluster represents substance information and contains 10 subblocks. They broaden the information about chemical, biological, physical properties of corresponding foodstuffs and beverages. Date mark always contains different figures. There may be sentences: best before end, best before, expiry date 11/2021. In other cases, there occur introductory sentences explaining where to find the definite date mark: for best before date see side of pack, for 
display until and use by, see front of pack, display unit: 21/Jul, use by 23/Jul ((A) ASDA, (B-C) Shortcrust Pie). The subblock List of Ingredients is represented with the title "Ingredients". The order of ingredients starts with the biggest amount of substances, the last is the ingredient with the smallest amount. This subblock may cause some difficulties because only some recipients can understand the meaning of chemical terminology lexemes: Ingredients: enriched egg noodle product [wheat flour, egg yolk, iron, thiamine mononitrate (vitamin E), riboflavin (vitamin B2), folic acid], salt, maltodextrin, cornstarch, carrot powder, chicken fat, chicken, onion powder, yeast extract, natural flavors, turmeric (for color), celery, parsley, non-fat milk, egg yolk dehydrated. Some lexemes (vegetable oil, cheese, sugar, fish, animal oils, vegetable oils and fats, vegetable and animal oils) may substitute specific terminology lexemes for better understanding. If the usage of terminology lexemes is obligatory, they may be followed with description, explanation, which is mostly connected with such chemicals as additives, preservatives, sweetenings, colorings, flavourings. Lot Identification subblock indicates the product traceability. It is always represented in the preposition with letter $L$ (L2 01:31:58). There are some variations of identity when Lot Identification understood from the phrase best before, use by (Best before 13 Jan 21). Net Content subblock is indicated on food labels. This verbal element contains 3 codes: weight, measure system, guarantee of precision $(750 \mathrm{~g} \mathrm{e})$. The letter $\boldsymbol{e}$ indicates that the packaged product has been checked out and passed through the inspection, the weight corresponds to the indicated figures. The next subblock has different subtitles: Nutrition labelling (UK), Nutrition Facts Label (USA, Canada), Nutrition Information $(E U)$ is obligatory if there are any nutrition claims: low fat, reduced fat, light, high fiber. The next subblock Nutrition claims is closely connected with the subblock Nutrition Information or it may be recognised as a part, fragment of nutrition labelling. There is some resemblance between the list of ingredients and nutrition labelling. Nutrition information is given in the table form. It makes the understanding quick and easy: total fat, total carbohydrate, 
protein. Amount is given per serving, grams, \%. Additional information may be given in calories with corresponding abbreviations $\mathrm{KJ}$, kcal. It is connected with the amount of a product: $100 \mathrm{~g} / 100 \mathrm{ml}$. The subblock Indication of Alcoholic Strength is obligatory for beverages containing more than $1.2 \%$ alcohol. This verbal element contains the lexeme alcohol or its abbreviation alc with corresponding figures and the symbol \% $\mathrm{vol}(5.5 \mathrm{alc} / \mathrm{vol})$. Health claim subblock should contain a list of facts which are permitted in UK Food Regulations, FDA, USA. Some of them contain lexical units with positive denotative meanings: reduces the risk of high blood pressure and stroke, reduces the risk of heart disease, reduces coronary heart disease risk. Health claims describe positive effects of some chemicals, substances: Calcium reduces osteoporosis risk. Fiber (fruit, vegetables, grains) reduces cancer risk. Soluble fiber (whole oats, psyllium seed husk) reduces coronary heart disease risk. Fruit and vegetables reduce cancer risk. Negative effects of certain chemicals, substances are indicated too: Sodium increases high blood pressure risk. Dietary fat increases cancer risk. dietary saturated fat and cholesterol increase coronary heart disease risk. Dietary sugar increases dental cavity risk. Health claim subblock contains lexemes reduce(s), increase(s) and the description of physiological effect, the chemical elements causing the certain physiological effect are on the initial position (calcium, sodium), there may be organic substances (fat, cholesterol, fiber, sugar, protein). Percentage labelling subblock is connected with the list of ingredients, net content, nutrition information, indication of alcoholic strength. It appears accompanied with a percentage symbol (100\% wholemeal flour, Alison 100\% wholemeal bread, now with 30\% more fruit, 100percent organic fruit and vegetables, 100\% sweet potato, pumpkin, apple and blueberries. \% Daily Value Total Fat $11 \mathrm{~g} 16 \%$, sodium $148 \mathrm{mg} 6 \%$ ). In some cases, there is a representation of ingredients in $g, m g, \%$. Percentage labelling functions as a doubling way of figure presentation using percentage scale. GMO Mark subblock occurs only in the case of plant product and it contains responding lexemes: no GM ingredients, GMO free. There is a new way of product 
categorisation using the opposition GMO::Organic. Organic natural products are popular now. This subblock is the last in the subblock order which creates a substance information subblock cluster. Condition information subblock cluster grasps four subblocks. The most essential is the Special Storage Condition subblock. This information is utterly necessary for a potential consumer of the foodstuffs. This information can be given in a special table or under the headline Storage or Other Information. Elliptical sentences are suitable here too. Imperative mood is appropriative here. (A) $A S D A$ (B-C) Shortcrust Pie (D) Storage: Keep refrigerated. Suitable for freezing. Freeze on day of purchase and consume within one month. Once defrosted, do not refreeze. Participial phrases are open here: Once defrosted. When stored in a refrigerator. If kept frozen. If the table is used for representing the information, it is possible to describe different conditions and treatment of corresponding foodstuffs. (A) Northern Catch, (B) Salmon Fillets, (D)

\begin{tabular}{|ll|}
\hline \multicolumn{2}{|l|}{ STORAGE INSTRUCTIONS: KEEP FROZEN } \\
\hline FOOD FREEZER* & UNTIL BEST BEFORE END DATE \\
\hline STAR MARKED* & UNTIL BEST BEFORE END DATE \\
\hline FROZEN FOOD COMPARTMENT & ONE MONTH \\
OR REFRIGERATOR & ONE WEEK \\
\hline ICE MAKING COMPARTMENT & 3 DAYS \\
\hline REFRIGERATOR OR OTHER COOL PLACE & 24 HOURS \\
\hline DO NOT REFREEZE ONCE DEFROSTED & $*$ MUST BE $-18^{\circ} \mathrm{C}$ OR COLDER \\
\hline
\end{tabular}

Health warning subblock may contain only one nominative sentence: (A) Newbury Phillips, (B) Organic Sesame, (C) Pitta, (D) Suitable for vegetarians. (A)Vitagermine, (B-C) Babynat, (D) Special texture for baby's small hand and mouth. Warning may be represented as a list of predicatives - names of substances causing 
allergy. These sentences may be negative in their meaning: gluten free; milk and lactose free; egg free; no artificial flavourings, colourings or preservatives; no GM ingredients. Government warning is an obligatory subblock for labels or packaging for alcohol and tobacco. This subblock has a definite headline Government Warning. Intentional contents have lexemes with negative denotative meaning. There occur nouns - names of diseases (lung disease, cancer, strokes, heart diseases, heart attack, impotence). Adjectives - intensifiers (fatal, serious, addictive) give additional meaning. Verbs of negative contextual meaning describe the action of corresponding chemicals (kill, harm, cause, damage, age, die, reduce (the blood flow), decrease, clog). Using the verbs in the form of the Present Simple actualizes the law meaning. On the associativecognitive level lexical units cigarette, smoking are connected with symptoms of maladies. Predicates of existence (be, contain) transfer these features of the products. Predicates of action are connected with the products (alcohol, tobacco). The Condition information subblock cluster contains the final (fourth) subblock of Instruction for use. It varies from one sentence to the text: (A) Nestlé, (B-C) Carnation, (D) Just add hot water. Subblock Microwave popping instruction contains 3 segments with the corresponding figure indications. This subblock contains the line of warnings, the pragmatic types of sentences used in this subblock is directive: Do not overcook as popcorn will scorch. There is a diffusive subblock cluster consisting of two closely related subblocks: (1) Advertisement claim, (2) Advertisement. The subblock Advertisement claim using minimal lexico-grammatical means in a concentrated way (elliptical sentences, in particular) represents the main features of foodstuff as an object of description. (A) Cadbury, (B) Dairy milk, (C) Strawberries and cream, (D) Extra value pack. Double Wall Vacuum Insulated. Stainless Steel Inner and Outer Walls. New. 10 more bags than other brands. New. Summer Limited Edition. Information represented in the Advertisement claim subblock has an attractive function. Advertisement subblock grasps some functions simultaneously: argumentative, persuasive, emotive, evaluative. All 
these functions may be reflected in a small text: (A) Kellog's, (B-C) Corn Flakes, (D) There is nothing quite like them. The advertisement subblock text may be extended: (A) Hellmann's (B-C) Reduced Calorie Mayonnaise, (D) Simply nothing better. Hellmann's Reduced Calorie Mayonnaise is great for any kind of salad: use it as a dip, a topping or a dressing. Make a meal of your salad and enjoy watching your waistline. This text is closely connected to the Instruction for Use subblock. All these texts of eatables become the centre of message. The foodstuffs are actualized with definite naming units and features of products. Semes of predicates confirm the presence of the features described and annumerated. These semes force the addressee to the action.

Coherence in texts of labels and packaging for eatables and beverages is realised involving the logical order of corresponding text blocks. The Chain of blocks is represented in the order of A-brand text block, B-individual text block, $\mathbf{C}$-genitive text block, D-functional descriptive text block.

Cohesion is the next text category which occurs in the label and packaging texts. this category reflects how the components of the surface texts, i.e. the actual words we hear or see, are mutually connected with a sequence [13, p.23]. The surface components depend upon each other according to grammatical forms and conventions. Cohesion rests upon grammatical dependence [15, p.199]. Cohesion is divided into grammatical and lexical. Grammatical cohesion includes repetition, synonyms, superordinate, general words [17, p.3-12]. Taking into consideration the food and drink nature of label text construction, the repetition of lexical units in corresponding text blocks - nominative components is the most evident mechanism of cohesion in the integrated naming complex. The repetition is realised between two separate text blocks. It occurs when a certain text block is completely repeated in another text block. This type of repetition (reiteration) is recognised as a complete interblock. (A) Hellmann's (B-C) Reduced Calorie Mayonnaise, (D) Simply nothing better. Hellmann's Reduced Calorie Mayonnaise is great for any kind of salad: use it as a dip, a topping or a dressing. Make a meal of your salad and enjoy watching your 
waistline. Complete repetition is represented with models: $(\mathbf{A} \rightarrow \mathbf{D})$ (A) Hellmann's $\rightarrow$ (D) Hellmann's; (B $\rightarrow$ D) (B) Reduced Calorie $\rightarrow$ (D) Reduced Calorie; $(\mathbf{C} \rightarrow \mathbf{D})(\mathbf{C})$ Mayonnaise $\rightarrow(\mathbf{D})$ Mayonnaise. Another model of interblock repetition occurs when a corresponding text block is reflected in another text block partially: (A) Jacob's, (B) Cheddars, (C) Cheese biscuits, (D) made with real cheese. $(\mathbf{C} \rightarrow \mathbf{D})$ (C) Cheese $\rightarrow$ (D) cheese. The partial repetition occurs in the text: (A) Milupa, (B) Sunshine Orange, (C) A delicious breakfast, (D) prepared with the real oranges and fortified with vitamins and minerals. $(\mathbf{B} \rightarrow \mathbf{D})(\mathbf{B})$ Orange $\rightarrow(\mathbf{D})$ oranges. The same partial interblock repetition with some specification occurs in the label: (A) E.Smithwick \& Sons Ltd, (B) Smithwick's Ale, (C) beer, (D) established in 1710. Kilkenny. Ireland 330ml. 5.5\%alc/vol. $(\mathbf{A} \rightarrow \mathbf{B})$ (A) Smithwick $\rightarrow$ (B) Smithwick's. There happens the interlanguage complication in the process of partial repetition $(\mathbf{B} \rightarrow \mathbf{C})(\mathbf{B})$ Ale $\rightarrow$ (C) beer, the complication is connected with synonyms belonging two different languages. Ale as a lexical unit has the Celtic origin while beer belongs to the common Germanic vocabulary and is represented in English spelling variant (Celtism $\rightarrow$ Anglicism). All the examples demonstrate the case of interblock repetitions. The inner text block repetition occurs in functional descriptive text block. It happens in the Instruction for Use subblock involving the repetition of some lexical units. This multilexical unit repetition forms a firm way of cohesion. The common model $(\mathbf{D}) \rightarrow$ (D) dominate within the whole subblock involving for reiteration four lexical units (microwave, popping, oven, popcorn).

Microwave popping instructions

1 POP

Unfold one popcorn bag and place in center of oven with INSTRUCTION SIDE UP. Using full power (HIGH) set timer for 5 minutes. Popping time may take as many as 2 minutes or as many as 5 minutes because microwave ovens vary. DO NOT LEAVE MICROWAVE UNATTENDED WHILE POPPING.

2 LISTEN CAREFULLY 
Stop microwave when rapid popping slows to 2 to 3 seconds between pops. Do not overcook as popcorn will scorch. Remove bag from oven carefully (It's Hot!).

\section{OPEN BAG}

Open bag with a tug on top diagonal corners. Avoid contact with escaping steam. Enjoy!

Do not reheat unpopped kernels or re-use bag.

Do not place bag on paper, plastic microwave cookware aura turntable which were not an original part of the oven.

Popping performance in small cavity ovens may improve by placing bag on an inverted microwave-safe plate.

The reiteration model (D) $\rightarrow$ (D) between the parts of subblock.

part $1 \rightarrow$ part 2 (oven $\rightarrow$ oven, popping $\rightarrow$ popping, microwave $\rightarrow$ microwave, popcorn $\rightarrow$ popcorn)

part $2 \rightarrow$ part3 (microwave $\rightarrow$ microwave, popping $\rightarrow$ popping, oven $\rightarrow$ oven)

part $1 \rightarrow$ part3 (microwave $\rightarrow$ microwave, popping $\rightarrow$ popping, oven $\rightarrow$ oven)

The same model happens with one and the same subblock part:

part $1 \rightarrow$ part 1 (popping $\rightarrow$ popping, microwave $\rightarrow$ microwave, oven $\rightarrow$ oven)

part $2 \rightarrow$ part2 (pops $\rightarrow$ popping)

part3 $\rightarrow$ part3 (microwave $\rightarrow$ microwave, oven $\rightarrow$ oven)

This specific iteration with the functional descriptive text block, in the boundary of instruction for use subblock provides a stronger variant of cohesion if compared to the reiteration between different text blocks. It is the reflection of compensation mechanism when the reiteration between different text blocks does not happen.

Conclusion. The results of the textual analysis prove that the integrated naming complex (INC) corresponds to text or textual structure. It means that the food, beverage labelling and packaging text fulfils two leading standards of textuality, they are cohesion and coherence. The coherence happens in labelling and packaging texts. It is recognized as a strict logical order of four text blocks: $\mathbf{A}$ - brand text block, B - individual text block, $\mathbf{C}$ - genitive text block, D - 
functional descriptive text block. The cohesion is realized on the textual level and it involves the mechanism of repetition. The repetition may be complete or partial, noncomplicated and complicated. Repetition occurs between different text blocks and within one and the same text block. Among the seven standards of textuality the standard of intertextuality appears promising and perspective for further textual investigations of food and beverage labelling and packaging texts.

\section{REFERENCES}

1. Beaugrande, R. A. de, Dressler, W. (1981). Introduction to text linguistics. London, New York: Routledge, 286 p. [in English].

2. Beaugrande, R. A. de. (1980). Text, Discourse, and Process. Norwood N. J.: Ablex, 351 p. [in English].

3. Dijk, T. A. van. (1977). Text and context explorations in the semantics and pragmatics of discourse. London, New York: Longman, 261 p. [in English].

4. Dressler, W. (2001). Introduction to Text Linguistics [Einführung in die Textlinguistik]. Tubingen: de Gruyter, 303 p. [in German].

5. Fair Packaging and Labeling Act. Federal Trade Commission Protecting America's Consumers. URL: https://www.ftc.gov/enforcement /rules/rulemaking-regulatory-reform-proceedings/fair-packaging-labeling-act

6. Fauconnier, G., Turner, M. (2000). Compression and global insight. Cognitive Linguistics, 11 (3/4), 283-304 [in English].

7. Food Labelling and Packaging. URL: https://www.gov.uk/foodlabelling-and-packaging/overview

8. Food labelling - what you must show. URL: https://www.gov.uk/ food-labelling-and-packaging/food-labelling-what-you-must-show

9. Food Standards Code (Australia, New Zealand). URL: https://www.foodstandards.gov.au/code

10. Galitska, E. A. (2016). Semantics of perfume and cosmetic naming in the social stratification aspect. Studia Philologica, 10, 53-58 [in English].

11. Gardenfords, P. (2000). Conceptual spaces: The geometry of thought. Cambridge, London: The MIT Press, 308 p. [in English].

12. Gentner, D. \& Goldin-Meadow, S. (2003). Language in mind. Advances in the study of language and thought. Cambridge, Massachusetts, London: The MIT Press, 528 p. [in English]. 
13. Halliday, M., Hasan, R. (1976). Cohesion in English. London, New York: Longman, 374 p. [in English].

14. Hendriks, P. (2004). Coherence Relations, Ellipsis and Contrastive Topics. Journal of Semantics, 21 (2), 133-135 [in English].

15. Knott, A., Sanders, T., Oberlander, J. (2001). Levels of representation in discourse relations. Cognitive Linguistics, 12 (3), 197-209 [in English].

16. Labelling Requirements for Alcoholic Drinks. https://www.merton.gov.uk/ alcoholguidance.pdf

17. Melrose, R. (2000). Text semantics and the role of interpretation in modeling indeterminacy. Journal of literary semantics, 29 (1), 1-44 [in English].

18. Talmy, L. (2000). Force Dynamics in Language and Cognition. Towards a Cognitive Semantics. Concept Structuring System, 1, 409-470 [in English]. 